\title{
Comprehensive School and Vocational Training in Spain. A Longitudinal Approach from the Transition from Lower to Upper Secondary Education
}

\author{
Rafael Merino *(D), Ona Valls (D) and Albert Sánchez-Gelabert (D) \\ Department of Sociology, Autonomous University of Barcelona, 08193 Cerdanyola del Vallés, Spain; \\ ona.valls@uab.cat (O.V.); albert.sanchez@uab.cat (A.S.-G.) \\ * Correspondence: rafael.merino@uab.cat
}

Citation: Merino, R.; Valls, O.; Sánchez-Gelabert, A. Comprehensive School and Vocational Training in Spain. A Longitudinal Approach from the Transition from Lower to Upper Secondary Education. Educ. Sci. 2021, 11, 101. https://doi.org/ 10.3390/educsci11030101

Academic Editor: In Heok Lee

Received: 15 January 2021

Accepted: 24 February 2021

Published: 2 March 2021

Publisher's Note: MDPI stays neutral with regard to jurisdictional claims in published maps and institutional affiliations.

Copyright: (C) 2021 by the authors Licensee MDPI, Basel, Switzerland. This article is an open access article distributed under the terms and conditions of the Creative Commons Attribution (CC BY) license (https:// creativecommons.org/licenses/by/ $4.0 /)$.

\begin{abstract}
Fitting vocational training into the Spanish education system has been challenging and problematic because two objectives are trying to be fulfilled; the first to supply skills for the productive system and the second to be an alternative option for the young people who do not follow the academic track. Moreover, the political vicissitudes of recent decades have added to the difficulties involved in balancing these requirements. In Spain, both the economic agents and the education system itself with its academic inertia have relegated vocational training to a subordinate position, able to attract mainly young people with lower academic achievement and largely rejected by families with a higher educational level. The assumption was that the introduction of a comprehensive secondary education in the 1990s would provide parity between the academic and the vocational tracks. However, the comprehensive nature of this system was not fully applied, with students in many schools separated by ability levels, and in fact having little impact on the social bias of the students choosing vocational training. The empirical contribution of this study is based on a survey carried out among 2056 students from Barcelona in their last year of compulsory secondary education in 2013-14 and who continued in full-time education, be it baccalaureate or vocational training. The main result shows that comprehensive education improves school success and decreases the vocational orientation of students from low social backgrounds.
\end{abstract}

Keywords: educational pathways; education reform; secondary education; educational inequalities

\section{Introduction}

The debate about how vocational training fits into education systems has a long and inconclusive tradition in both academic circles and educational policy making [1]. It is longrunning in that it dates back to when the modern education systems were being constructed at the end of the nineteenth century in response to the need to recruit manpower within a context of expanding industrial capitalism, and it is inconclusive because many different stakeholders with conflicting interests intervene in the definition of vocational training, and all this in a context of rapidly changing economic needs and demand for the skills and competencies required to meet the new economic and social challenges [2]. In short, there is a strain between vocational training as a secondary education track specifically designed to supply the skills required by the labor market and a comprehensive secondary education that develops basic citizen skills, and where either curriculum differentiation between the two tracks is postponed for as long as possible or vocational training is presented as nonformal education. The inherent problem with the first is equity because early vocational training tends to be chosen by students from a low social background, and the problem with the second is the design of the curricula and attention to the diversity of young people's motivations and interests. Spain, as a country of the European Union, shares the education and training strategy that established a reduction of early school leaving to $10 \%$ by 2020 , and the promotion of vocational training as a key strategy in the reduction of early 
school leaving [3]. That is why it has been and is so important in the debate in Spain on the placement of vocational training in post-compulsory secondary education.

The aim of the present paper is to analyze the interdependence between vocational training and lower secondary education in Spain; specifically, how the curricular organization and the management of heterogeneity affect the profile of students entering vocational training. In order to provide a theoretical, historical, and institutional contextualization of vocational training in Spain, the first section of the paper offers a conceptual framework of the different vocational training systems. It also includes a brief explanation of secondary education in Spain, as a result of the evolution of the educational reforms of recent decades. The second section is devoted to the explanation of the model of analysis with the hypotheses in relation to the aim of the research, the connection between lower secondary education and vocational training, as well as the empirical strategy followed. Last, some conclusions relevant to the study of educational inequalities and policies are drawn.

\section{Theoretical Framework and Literature Review}

\subsection{Vocational Training Systems}

The fit between vocational training and the different education systems depends on historic, cultural, and economic processes specific to each country and how they have responded to the phenomenon of educational expansion beyond primary school.

According to Buechtemann and Verdier [4], there are five ideal types of vocational training systems. See Figure 1:

\begin{tabular}{|c|c|c|c|c|c|}
\hline & Professional & Academic & Universalistic & Market Oriented & Market Oriented Organized \\
\hline $\begin{array}{l}\text { Initial training } \\
\text { agent }\end{array}$ & Company & School & $\begin{array}{l}\text { Educational } \\
\text { community }\end{array}$ & Consumers & Guided individuals \\
\hline $\begin{array}{c}\begin{array}{c}\text { Regulation } \\
\text { agents }\end{array} \\
\end{array}$ & $\begin{array}{l}\text { Social actors on } \\
\text { branches scope }\end{array}$ & School & Policy makers & Auctioneers & Skills recognition agencies \\
\hline $\begin{array}{l}\text { Goal vocational } \\
\text { education and } \\
\text { training (VET) }\end{array}$ & Professional rules & $\begin{array}{l}\text { Signal of } \\
\text { aptitudes }\end{array}$ & Social citizenship & Human capital & Human and social capital \\
\hline Shortcoming & $\begin{array}{l}\text { Stigmatization of non- } \\
\text { qualified young people }\end{array}$ & $\begin{array}{l}\text { Strong social } \\
\text { inequalities }\end{array}$ & $\begin{array}{c}\text { Inflation of } \\
\text { collective costs }\end{array}$ & $\begin{array}{l}\text { Underinvestment } \\
\text { in training }\end{array}$ & Lack of incentives \\
\hline
\end{tabular}

Figure 1. Vocational training systems.

According to Buechtemann and Verdier, there are no pure models, but rather each country is a socio-historical configuration with a combination of the different models depending on the context and the social and institutional stakeholders involved.

The education system in Spain is traditionally very academic with a highly undervalued vocational training offer. Elements of the market model and the organized market have progressively been incorporated into the system, in the first case particularly into vocational training outside the education system, and the second evidenced by professional certification and the creation of accreditation agencies. Furthermore, reforms along the lines of the professional model (taking the German dual training model as a particular reference) have been under consideration for some time, but the sectoral stakeholders involved are very weak [5]. However, even with these reforms, the Spanish model is still very much anchored in the academic model. This means that the connection with the rest of the educational system is very important, particularly with lower secondary education, and with the reproduction of social inequalities through the distinction between the academic and professional pathways.

The educational expansion that took place in developed countries from the 1950s and 1960s onwards posed a challenge to secondary education: to transform from being the precursor to higher education, and therefore selective, to being a practically universal educational stage and, therefore, a continuation of primary education. In curricular terms, 
this continuity could be achieved in two ways: by extending the existing curriculum where possible, which would promote the comprehensive reforms, or by differentiating between the more academic and the more applied or vocational tracks. The comprehensive reform consists of setting up a unified curriculum at least up to the compulsory age limit and delaying as much as possible the choice or assignment of students to differentiated tracks. In terms of equity, this discussion about the curricular model is not neutral given that the comprehensive reforms were hailed as a mechanism to neutralize social inequalities while maintaining different school tracks became a mechanism for social and/or racial differentiation [6]. This discussion had already taken place in the USA in the 1920s, with John Dewey's defense of the unified curriculum and David Snedden's [7] defense of social efficiency and the adaptation of school to social needs.

In Europe, the comprehensive reforms were most successful in the Scandinavian countries, despite being implemented in many other countries [8,9] including Germany, where the vocational training system is characterized by the early separation of students depending on achievement and where the introduction of a comprehensive system has been driven by expectations regarding later educational tracks $[10,11]$. To this effect, and in the words of Raffe [12], we could say that there were three models: unified, tracked, and linked. The unified model, represented by the Scandinavian countries, set out a single curriculum in lower secondary education and integration of the academic and the vocational tracks in higher secondary education. The tracked model, implemented in the Germanic countries, involved early separation in lower secondary education, continuing in the different higher secondary education tracks. The linked model was a combination of the previous two, with a lower secondary education that tended to be comprehensive and a higher education system with interconnected tracks, found in Spain $[13,14]$ and France and partly implemented in the United Kingdom.

Another issue is how the comprehensive curriculum of whatever type combines with the management of heterogeneity. According to Mons [15], there are four models for this management:

- Separation model: fixed tracks and the extensive use of repeating a year for students with low school achievement, as is the case in Germany.

- Individualized integration model: comprehensive model and with no repeating a year, like in Finland.

- À la carte model: comprehensive model with a small percentage repeating a year and curricular diversification, as in the USA.

- Uniform integration model: comprehensive model with the intensive use of repeating a year and curricular diversification. This is the case of Spain.

The management of heterogeneity in the separation model is based on grouping students with different levels of achievement in different tracks, and often in different schools. In the countries that have opted for a comprehensive model to manage heterogeneity, it has been based on curricular diversification, repeating a year in some cases, and streaming. These practices tend to undermine the comprehensive curriculum model by introducing some internal tracks that reinforce educational and social inequalities [16]. The main argument in favor of streaming is that it improves the achievement of all students, which is the same argument used by its detractors, who claim that less able students tend to perform better if they are in mixed classes with the more able students. Empirical study has found very modest results supporting streaming leading to improvements in achievement [17], while it certainly leads to increased racial and class segregation given that there were more students with a low social background and from minority ethnic groups in the low performing groups, negatively affecting their self-image and expectations [18]. A study carried out in the UK showed that gifted students from low social classes obtain better results in non-comprehensive schools [19]. This study was based on a quasi-experiment that was carried out after the comprehensive reform was implemented in the UK in the 1960s when the achievement of young people in comprehensive schools and schools with an academically selected intake could be compared according to social origin. In Spain, 
it has been observed that some schools in deprived areas implement a strict streaming system to prevent the influx of gifted students and to attract middle-class youngsters, with selective groups or what is known as "golden enclaves" [20].

\subsection{Vocational Training in Spain: Partial Success of the Comprehensive Reform}

In Spain, the strain between the educational and economic purposes of vocational training apparent during the last decades has remained unresolved. In contrast to the Germanic model, the business and economic stakeholders have had neither influence nor involvement in the direct or agreed provision of vocational training, and neither have they recognized the qualifications or certificates awarded for this training, with some exceptions that have increased in number in the last years with the consistent implementation of dual training. Furthermore, unlike the case of the Nordic model, the political and social stakeholders that champion egalitarianism have not had sufficient influence to be able to implant an effectively comprehensive education system, among other reasons because of the large influence the private sector has in the provision of training, but also because of the academic inertia of the education system itself. In 1970, an education law was enacted which attempted to combine the educational and economic purposes of education. For the first time, a vocational training track was incorporated into the education system, justified by the need to improve the human capital in a booming economy, and in the line of the human capital theory consolidated internationally in the 1960s. Nonetheless, this vocational training was conferred a dual educational purpose: part of the curriculum developed which we would currently call basic competencies, while passing vocational training could also lead to further study, and even to accessing university.

The law failed for various reasons [21]. One of the main reasons for Spain is that it was a law enacted under Franco's dictatorship and so lacked democratic legitimacy. The country's economic agents lacked the force to get involved in training, except in the more economically advanced regions like Catalonia and the Basque Country [22]. Moreover, the economic crisis of 1973 further weakened the investment and contractual capacity of young people recently qualified in vocational training. The more progressive social and political stakeholders criticized the law, accusing it of being classist because it established the early selection, at 14 years old, of the students destined to study baccalaureate and those heading for vocational training. The latter were the students with the worst educational achievement and from the lower social classes, which would contribute to the reproduction of educational inequalities, in the line of the 1970s trends in sociological criticism [23].

Despite the criticisms aimed at it and its weaknesses, vocational training was fairly successfully implemented in Spain in terms of demand [24], with some areas such as electronics and administration expanding enormously, although with a clear gender bias that can still be evidenced today [25]. Furthermore, once the worst of the economic crisis had passed by the end of the 1970s, labor market insertion rates had risen [26]. Nonetheless, the criticism intensified. The business sectors complained that the training received was too much like a classic school education and did not meet the needs or requirements of the companies. The progressive social, union, and political stakeholders denounced the marked classicism of a dual and selective system that did nothing to achieve equal opportunities. Furthermore, behind the relative success of vocational training in terms of labor demand and insertion, there was a high dropout rate [14], leading to many young people joining the most precarious segment of the labor market and with little chance of re-entering the education system.

In the 1980s, once the process of the transition to democracy was fairly well consolidated, a reformist agenda was adopted with a series of educational reforms that were laid out in the 1990 Organic Law on the General Organisation of the Education System (LOGSE). This law was criticized by the liberal sectors as too egalitarian and promoting mediocrity, and by the more egalitarian sectors as not thorough enough and lacking ambition in terms of its very objective to reduce inequalities. Despite the many political and social vicissitudes 
that have occurred in Spanish politics in the last 30 years, the architecture of the education system outlined in this law remains in place to this day [10].

This architecture is very succinctly summarized in the Figure 2:

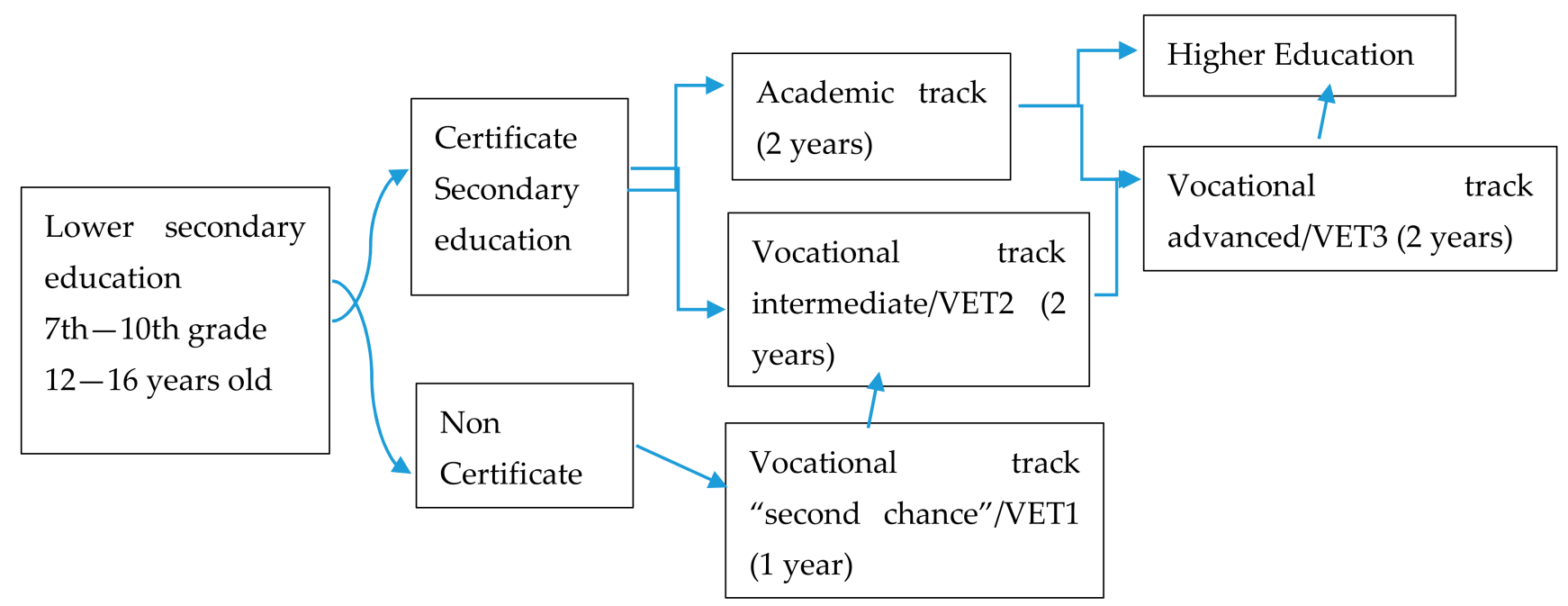

Figure 2. Structure of secondary education in Spain.

Lower secondary education was and remains the keystone of the comprehensive model. It was extended to 16 years old to silence criticisms of a system that separated young people on different pathways at 14 years old, and a unified curriculum was designed which in theory would prepare young people to choose between the higher education academic and vocational tracks on an equal footing. Hence, gaining the secondary school leaving certificate was a mandatory requisite for accessing the two. It was assumed that if the same access qualification were required, this would help to ensure parity in the prestige accorded to the two tracks. A higher vocational training was also created, one of the entry requirements for which was baccalaureate, in theory making this qualification and university equally prestigious, although the intermediate vocational training qualification was also sufficient to enter the higher level (initially with many restrictions, but much less so since the 2013 reform). Some second chance training programs were created for the young people that did not gain the secondary school leaving certificate which took place more outside than as part of the education system but could lead to accessing intermediate vocational training in some circumstances.

This architecture was implemented in the mid-1990s with many setbacks and contradictions, as the publication of the official education statistics and the first empirical studies on inequalities in educational opportunities showed [26]. First, the foreseen dropout rate of $5 \%$, in practical terms at the threshold of special education [13], was surpassed sixfold in the first year, registering $30 \%$ and thereby excluding almost a third of students from the education system every year. This figure has since gone down to $17 \%$ (latest figures for the 2017-2018 academic year), although there is ongoing debate about how this reduction has been achieved.

A further consequence of extending compulsory education was the greater heterogeneity in the composition of schools. This had been foreseen and a series of organizational and teaching measures put in place to manage it, despite their implementation deriving in curricular diversification and management practices that contravened the sociopedagogical fundamentals of comprehensive education. One of these practices is ability grouping. From the constructivist theory of learning, it is assumed that less able students learn better and more when they cooperate with more able students, who themselves consolidate their learning when they teach their lower achieving classmates. However, many teachers and management teams do not share this perspective, or do not feel equipped to put this theory into practice, especially in contexts where social and school segregation is high [26]. There 
are many dimensions to ability grouping and it can be applied to just some subjects or to entire groups, either in the last year of secondary education or alternatively right from the very first year. There are no global data, but according to some case studies, ability most frequently occurs in the last year of compulsory secondary education and in the core subjects of math and language [26]. Another management mechanism is repeating a school year for students who do not pass a minimum number of subjects. The repetition rate in Spain is one of the highest in the OECD (according to indicators for the 2017-2018 academic year, 30\% of 15-year-olds are not in the school year they should be theoretically), generating criticism for these types of measures due to the economic cost involved and their ineffectiveness in terms of the skills acquired, while leading to no substantial reduction in the repetition rate. Nonetheless, there is a clear correlation between repeating a year and dropout and/or re-entering the education system via level 1 vocational training (VET1, Vocational Education and Training level 1, in Spanish Formación Profesional Básica) [27]. The third and last tool to manage heterogeneity is curricular diversification, which in some cases consists of incorporating subjects or even applied learning tracks in what could be considered a pre-vocational or level 0 training. There is no aggregated data on the percentage of students who follow these differentiated itineraries, but it seems reasonable to assume that they are low performing students with low school engagement, from a low social background, and with little probability of continuing to post-compulsory education [28].

Ability grouping and curricular diversification lead to a paradox in terms of the evaluation at the end of compulsory education because the certificate is the same even though the track taken and the competencies acquired up to this point are different. This is also what leads to the reproduction of the difference between accessing the academic and the vocational tracks, because it is the student's achievement that dictates their choice as to which path they take [29], as will be seen in the empirical section.

If accessing VET2 (Vocational Education and Training level 2, in Spanish Ciclos Formativos de Grado Medio) and baccalaureate are equivalent in terms of the entry requirements, then the requirements for accessing VET3 (Vocational Education and Training level 3, in Spanish Ciclos Formativos de Grado Superior) should also be equivalent to passing baccalaureate and being able to enter university. While university entry has always been subject to passing an entry test and VET3 not, thereby defying the objective of equivalency, what is true is that accessing VET3 from VET2 was not originally allowed to prevent a long vocational training track being created that would only serve to reinforce its secondary and inferior role with respect to the baccalaureate-university track. However, what this closure in fact served to do was increase inequality in educational opportunities, because the higher the academic barrier the lower the number of young people from lower social backgrounds accessing the type of study [25]. In fact, demand for a link between VET2 and VET3 was so high that what has happened is that generally agreed accessways between the two levels evolved, to the point where the 2013 education reform specifically fixed some quotas for direct access from the lower to the higher level.

\section{Method}

As already mentioned, there are no aggregated data demonstrating the reach of the heterogeneity management practices employed in compulsory secondary education, and even less their effect on the probability of transitioning to post-compulsory education. However, an empirical approach can be made based on a longitudinal study carried out in the city of Barcelona among a sample of 2056 young people born in 1998 and who in the 2013-2014 academic year were either in the 10th grade or in lower grades if they had repeated a grade. The sample also included youth from previous graduating classes who were enrolled in 10th grade. As explained above, the 10th grade is the last compulsory grade and then students begin the transition to post-compulsory secondary school. The study had three waves of follow-up in the 2014-2015, 2015-2016, and 2016-2017 school years, but for this article only data from the first and second waves will be used, just at 
the transition from compulsory to post-compulsory school. The sample of students was obtained from a sample of 27 secondary schools, segmented according to their ownership, and a complexity indicator decided by the education department based on the number of foreign-born students and/or students with social problems. The selection of the schools was carried out jointly with the local education authority, based on the criteria established for the segmentation of the sample and the accessibility granted by the local education authority itself. The aim was to have a representative sample of 2000 young people in the city of Barcelona. This research detected that there were schools that organized the students into groups based to some degree on achievement, enabling us to compare their students' academic results and transitions, according to the following hypothesis:

H1. Students with a low social background are overrepresented in the lower-level groups.

H2. Students with a low social background with high achievement in homogenous groups are more likely to gain the certificate.

H3. Students with a low social background and low achievement in homogenous groups are more likely to choose the vocational track.

The analysis model was constructed from the following variables:

Certificate: A proxy was constructed for this variable as it was not directly collected in the survey. In the 2014-2015 academic year, the sample group of students were studying baccalaureate or VET2, having successfully completed compulsory secondary education. The rest of the students were either repeating a year or had dropped out, in which case they were considered to have not gained the school leaving certificate, despite some of those who had dropped out may having passed it.

2014-2015 track: A dichotic variable depending on whether the student was enrolled in the academic track (baccalaureate) or the vocational track (VET2) in the academic year 2014-2015.

Family educational level: this variable is a proxy of the students' social origin. Previous studies [30] have shown that this is the best approximation. The three categories were constructed based on the parents' educational level: university level (one or both parents with a university education), secondary level (parents without a university education, but one or both with higher secondary studies), and primary level (both parents with a maximum of a compulsory education).

Achievement: the score obtained by the students in the external math and language tests (similar to the test set by PISA) was chosen to measure achievement. This can be considered a proxy variable because we did not have access to student achievement measured by the grades obtained in the exams set by the schools themselves, which are those used to decide if the student can gain the school leaving certificate.

Repeating a year: the students in the sample group were asked if they had ever repeated an academic year in either the primary or the secondary phase, separating them into two groups, those who had repeated at least one year and those who had never repeated a year.

Student groups: A proxy was used because the schools did not divulge information about student ability groupings. We decided to use the achievement variable and to compare the averages of the different groups in each center. If the averages were similar it was deduced that the group was heterogenous, and if there was a certain difference between the averages the groups were assumed to have been separated by levels of achievement, or in other words they were homogenous groups, which would explain the differences in the averages.

Sex: the male/female variable was used in all the analyses as a control variable.

The analytical strategy was based on a descriptive analysis of the variables and the binomial logarithmic regressions (Software SPSS 20. 95\% level of confidence). 


\section{Results}

\subsection{Descriptive Data}

Table 1 shows the descriptives of the variables used in the analysis.

Table 1. Descriptives of the variables.

\begin{tabular}{cccc}
\hline Variable & Categories & $\%$ & $\mathbf{N}$ \\
\hline \multirow{2}{*}{ Sex } & Male & $52.2 \%$ & 1074 \\
& Female & $47.8 \%$ & 982 \\
\hline \multirow{2}{*}{ Family educational level } & Compulsory level education & $33.5 \%$ & 669 \\
& Non-university secondary level education & $25.7 \%$ & 515 \\
& University level education & $40.8 \%$ & 816 \\
\hline \multirow{2}{*}{ Achievement } & Low & $49.2 \%$ & 830 \\
\multirow{2}{*}{ Students groupings } & High & $50.8 \%$ & 857 \\
& Homogenous & $54.0 \%$ & 878 \\
\multirow{2}{*}{ Repeated an academic year } & Heterogenous & $46.0 \%$ & 748 \\
\hline \multirow{2}{*}{ Certificate (proxy) } & Yes & $11.7 \%$ & 189 \\
& No & $88.3 \%$ & 1419 \\
\hline \multirow{2}{*}{$2014-15$ Course of study } & Yes & $89.6 \%$ & 1457 \\
& No & $10.4 \%$ & 169 \\
\hline
\end{tabular}

Of the 2056 young people who took part in the study, $23 \%$ were in years below year 10 , giving us a first indication of the extent to which repeating a school year is implemented in the Spanish education system. Therefore, only the 1687 youngsters who were in year 10 could be included in the analysis, in other words those who had taken the external competencies tests in math and language and could go on to year 11 if they passed the school leaving certificate.

Regarding the family educational level variable, calculated for the entire sample, there was a notably high presence of families with a higher education. This is the result of three decades of educational expansion in Spain and is especially marked in urban areas like Barcelona. This fact conditions the expectations and resources mobilized by families to support their offspring's schooling and their social mobility strategies through education, and in part explains the extremely high percentage of students that opt for baccalaureate rather than vocational training, the figures for which are $87 \%$ and $13 \%$, respectively.

The achievement variable is a continuous variable, with a range of 0 to 100 , a mean of 61.8 , and a typical deviation of 31.6. This continuous variable was used later for the regression analysis and was dichotomized by the median value for the descriptive analysis.

More than half the students (54\%) were in homogenous groups, or in other words they shared the same classroom with young people with similar achievement. This does not mean that they were in these ability groupings for the entire school day. The variable used refers to math and language, the core subjects for which classes organized by ability levels are most frequent. To this effect, it is also an approximation of the phenomenon of ability grouping because there are schools where this type of grouping is used less and schools that group by levels of achievement for all the subjects.

A total of $11.7 \%$ of the students in year 10 had repeated at least one year of primary or secondary school. This percentage was used for the regression analysis, although notably the figure was higher over the whole cohort. The qualification variable also has this bias and is a percentage of the sample of students in year 10 rather than a cohort variable, which would give a higher figure. The percentage of the sample who had not successfully finished secondary school and could therefore not continue in the education system was $10 \%$. Approximately $40 \%$ of these students had repeated a year and $15 \%$ were being directed towards the so-called second chance programs, which in most cases are vocational 
based training courses. Unfortunately, these sub-samples were too small to be considered in the analysis.

The survey asked about the geographical origin of the students as a proxy to measure their migratory background, but in a previous analysis it was detected that this variable has hardly any weight when controlled by the family educational level (27) and so it was decided not to include it in the analysis.

\subsection{Social Background and Ability Grouping (H1)}

Table 2 showing the social profile of the students in the homogenous and heterogenous groups was constructed to test the first hypothesis.

Table 2. Students in homogenous or heterogenous groups by family educational level.

\begin{tabular}{cccc}
\hline Family Educational Level & $\begin{array}{c}\text { \% in Homogenous } \\
\text { Groups }\end{array}$ & $\begin{array}{c}\text { \% in Heterogenous } \\
\text { Groups }\end{array}$ & N \\
\hline Primary level education & $72 \%$ & $28 \%$ & 441 \\
Non-university secondary level education & $49 \%$ & $51 \%$ & 423 \\
University level education & $46 \%$ & $54 \%$ & 762 \\
Total & $54 \%$ & $46 \%$ & 1626 \\
\hline
\end{tabular}

This table clearly shows the social bias in the ability groupings. The offspring of families with a low educational level have a much greater likelihood of being in a group separated by level than being in a heterogenous group. Table 3 shows if this bias is produced due to primary effects, or in other words because they have poorer achievement.

Table 3. Students in homogenous or heterogeneous groups by family educational level and achievement.

\begin{tabular}{|c|c|c|c|c|}
\hline Family Educational Level & Performance & $\begin{array}{c}\% \text { Homogenous } \\
\text { Groups }\end{array}$ & $\begin{array}{c}\% \text { Heterogenous } \\
\text { Groups }\end{array}$ & $\mathbf{N}$ \\
\hline \multirow{2}{*}{ Primary level education } & Low achievement & $80 \%$ & $20 \%$ & 289 \\
\hline & High achievement & $57 \%$ & $43 \%$ & 152 \\
\hline \multirow{2}{*}{ Secondary level education } & Low achievement & $61 \%$ & $39 \%$ & 221 \\
\hline & High achievement & $37 \%$ & $63 \%$ & 202 \\
\hline \multirow{2}{*}{ University level education } & Low achievement & $46 \%$ & $54 \%$ & 275 \\
\hline & High achievement & $46 \%$ & $54 \%$ & 487 \\
\hline Total & & $54 \%$ & $46 \%$ & 1626 \\
\hline
\end{tabular}

Table 3 shows that the achievement effect for the distribution of students in homogenous or heterogenous groups is produced in students with families with a lower educational level. Achievement has no effect for students with families with a university level education, meaning that organizing students by levels is more linked to the school's educational project [26]. The strong presence of students in homogenous groups with high achievement and families with no education may be due to the strategy of some schools of offering the "golden enclaves" referred to in the theoretical framework [20].

\subsection{Social Background, Achievement, Ability Grouping, and Educational Outcomes (H2 and H3)}

A regression analysis was carried out to analyze the incidence of this distribution in the probability of gaining the certificate and of choosing the academic or the vocational track and to test the rest of the hypotheses, first to see the marginal effects of each variable and second with the calculation of estimated probabilities for the interaction or the intersection of the different variables. As Table 4 shows: 
Table 4. Logistic regression of incidence in the probability of gaining the certificate and of choosing baccalaureate or VET2.

\begin{tabular}{|c|c|c|c|c|}
\hline & \multicolumn{2}{|c|}{ Certificate (Ref. no Certificate) } & \multicolumn{2}{|c|}{ Baccalaureate (Ref. VET2) } \\
\hline & B & $\operatorname{Exp}(B)$ & B & $\operatorname{Exp}(B)$ \\
\hline Male (ref. female) & 0.22 & 1.246 & $0.92 * * *$ & 2.51 \\
\hline \multicolumn{5}{|l|}{ Family educational level (ref. university education) } \\
\hline Primary level education & $0.838^{* *}$ & 2.312 & $1.68^{* * *}$ & 5.366 \\
\hline Secondary level education & 0.647 * & 1.909 & $1.352 * * *$ & 3.865 \\
\hline Repeating a school year (ref. not repeating a school year) & $1.199^{* * *}$ & 3.318 & $1.778^{* * *}$ & 5.919 \\
\hline Achievement (PCB) & $-0.029 * * *$ & 0.972 & $-0.022 * * *$ & 0.978 \\
\hline Homogenous groups (ref. heterogenous groups) & $0.916^{* * *}$ & 2.498 & $0.547 *$ & 1.728 \\
\hline Constant & 0.296 & 1.345 & -2.846 & 0.058 \\
\hline R2 Nagelkerke & & 35.4 & & 28 \\
\hline
\end{tabular}

There are some interesting results among the regressions. For example, the sex variable is not significant to explain the probability of gaining the school leaving certificate. This can seem counter-intuitive, but the most likely explanation is the interaction with repeating a year because boys are more likely to do so [30]. Sex does influence the choice between baccalaureate and vocational training, with the boys 2.5 times more likely to choose VET2 than the girls, despite it remaining a minority choice, as shown by the frequency analysis. This difference is undoubtedly linked to the vocational training offer because the fields of study are strongly influenced by gender connotations and the offer for boys is probably more attractive than the offer for girls, having a pull effect. Unfortunately, the sample does not allow us to analyze this training by fields of study, but other specific studies have reached similar conclusions [31].

The variable family educational level paints a very well-known picture in the sociology of education, with an importance nuance. The students with parent with a primary level education are almost twice as likely to not gain the certificate than the students with parents with a university education, with all other conditions in the rest of the variables including achievement being equal. This can be explained by the fact described previously, that the achievement variable is external to the centers, meaning that there is a bias between what this test measures and the assessment carried out by schools themselves. The well-known secondary effect can be seen in the choice between baccalaureate and VET2, in other words where the access qualification is the same, families with less educational capital tend to prefer vocational training up to five times more than families with more educational capital. Other studies [32] explain this fact by means of an expectation adjustment mechanism or the need to make a short-term investment that gains a return in the labor market.

Repeating a year is by far the variable with the greatest incidence in the probability of gaining the certificate, with the students whose education is extended in terms of the number of years being three times more likely to not gain the certificate. This may come as no surprise considering that they repeat because of low achievement. What is more surprising is the incidence of repeating a year in the option of vocational training, with students showing a six-times greater likelihood of doing VET2 if they have repeated a year of either primary or secondary education, when in theory they have the certificate that gives them the option of doing baccalaureate. This happens, as other studies have shown [28], because while students with low achievement or curricular diversification and those that have repeated the last year of compulsory secondary education are positively evaluated at least in schools, this evaluation is conditioned (a non-regulated condition intended for guidance purposes only) to these students choosing vocational training. The achievement variable confirms this affirmation because there is a strong negative correlation between higher grades and the probability of not gaining the secondary school certificate. Since 
the continuous variable was used in the regression model, the reading of the standardized coefficient is that for each extra point in achievement, the probability of not passing the qualification decreases by $3 \%$, obviously meaning that the probability of a student with a typical deviation of not gaining the certificate is practically zero. Worth noting is the incidence in the probability of choosing baccalaureate or vocational training: a point increment in achievement decreases the probability of choosing VET2 by $2 \%$, meaning that for a student with a typical deviation, the probability of choosing VET2 is very low. The analysis of repeating a year and achievement reinforces the image of vocational training being for low performing students, those who have repeated a year, and those who would find it difficult to follow baccalaureate, which is considered as the superior track of the system. This especially important point to explain how vocational training works in Spain will be re-examined in the conclusions.

Last, the variable of student groupings intervenes significantly in gaining the certificate, with a higher pass rate for compulsory secondary education among students who were in heterogenous groups. The students that were in homogenous groups were 2.5 times as likely to not finish school successfully, while for those in heterogenous groups the probability of not gaining the certificate was smaller, under equal conditions regarding the rest of the variables. These coefficients would strengthen arguments for a comprehensive education in terms of efficiency. However, they would also strengthen arguments regarding parity, because homogenous groups tend to channel more students towards the vocational track, in fact 1.7 times more so than heterogenous groups. A possible explanatory mechanism is the peer effect in the lower performing groups, tending to draw students more towards vocational training, although this could not be corroborated using the data from this sample.

Last, the central question of the analysis model is the interaction between the family educational level, achievement, and grouping students in relation to the model's two dependent variables. Table 5 shows the data based on the estimated probabilities derived from the regression model.

Table 5. Incidence model of the combination among the family educational level, achievement, and ability grouping in the estimated probability of gaining the qualification and of choosing baccalaureate or vocational education and training 2 (VET2).

\begin{tabular}{|c|c|c|c|c|}
\hline Family Educational Level & Achievement & Grouping & $\%$ Certificate/No Certificate & $\%$ Baccalaureate/VET2 \\
\hline \multirow{3}{*}{ Primary level education } & Low achievement & $\begin{array}{l}\text { Homogenous } \\
\text { Heterogenous }\end{array}$ & $\begin{array}{l}78 / 22 \\
89 / 11\end{array}$ & $\begin{array}{l}74 / 26 \\
83 / 17\end{array}$ \\
\hline & \multirow[b]{2}{*}{ High achievement } & Homogenous & $88 / 12$ & $92 / 8$ \\
\hline & & Heterogenous & $95 / 5$ & $95 / 5$ \\
\hline \multirow{4}{*}{ Secondary level education } & \multirow{2}{*}{ Low achievement } & Homogenous & $87 / 13$ & $80 / 20$ \\
\hline & & Heterogenous & $94 / 6$ & $88 / 12$ \\
\hline & \multirow{2}{*}{ High achievement } & Homogenous & $93 / 7$ & $95 / 5$ \\
\hline & & Heterogenous & $97 / 3$ & $97 / 3$ \\
\hline \multirow{4}{*}{ University level education } & \multirow{2}{*}{ Low achievement } & Homogenous & $91 / 9$ & $94 / 6$ \\
\hline & & Heterogenous & $96 / 4$ & $96 / 4$ \\
\hline & \multirow{2}{*}{ High Achievement } & Homogenous & $96 / 4$ & $98 / 2$ \\
\hline & & Heterogenous & $98 / 2$ & $99 / 1$ \\
\hline Total & & & $90 / 10$ & $89 / 11$ \\
\hline
\end{tabular}

The conclusion that the second hypothesis is not valid can be drawn from this table. The students with a low social background and high achievement in homogenous groups did not have a higher probability of gaining the school leaving certificate than the same profile of students in heterogenous groups (88 versus 95). In fact, in all the profiles the students in the heterogenous groups had a greater probability of gaining this certificate than the students in the homogenous groups. This result contributes to rejecting the idea that learning in homogenous groups is more efficient. However, the third hypothesis is 
validated because the students with a low social background and low achievement in homogenous groups are more likely to choose the vocational track in all the interactions $(26 \%)$, which would intervene in the problem of equity in the expectations of students in homogenous groups with low achievement. This phenomenon is also seen with students with families with a secondary educational level $(20 \%)$, but hardly intervenes with students with families with a higher education, among whom the propensity for the academic track is so strong that it affects a high proportion of students with low achievement, as a clear example of secondary effects [33]. Regarding heterogenous groups, although they show less social bias in terms of choosing the vocational training, they are more likely to produce students who choose the academic track, even among those with lower achievement, from which a peer effect can be deduced rather than those with a higher achievement tending to choose baccalaureate. This effect can induce very unrealistic expectations regarding the chances of passing baccalaureate and a greater tendency towards dropout [34].

\section{Discussion}

The results show that there is a strong link between low achievement in compulsory secondary education and a greater probability of choosing vocational training. However, this link has a social bias since it is not true for families with a high educational level, among whom there is a lot of pressure to enter the academic track given that the vocational track is considered to have a high risk of downward mobility. On the other hand, achievement has a greater weight among families with a low educational level because this adapts better to low expectations. Nonetheless, it is notable that even with low achievement, the number one option among students with families with a low educational level is still baccalaureate, probably because their mobility strategies are also linked to university and no clear link has been established between vocational training and chances of social promotion through work.

Of all the variables studied, the one that intervenes most in the vocational option is repeating a year, which is obviously related to low achievement. Repeating a year overrides the sex variable in terms of the academic or vocational tracks, rendering it insignificant. Another question regarding baccalaureate and vocational training, which falls outside the scope of this research, is whether they have strong gender preference connotations. Reducing the number of students that repeat a year could reduce the propensity for vocational training, although it would probably not stop the vocational track being associated with low achievement.

According to the data analyzed, the most comprehensive model, or the one with the least separation among groups, is the most efficient one in terms of the certificate awarded at the end of the compulsory level. On the other hand, the model in which there is the most separation by achievement affects students with a lower social background more, suggesting that there is a problem of equity in this model. For students from families with a higher educational level, distribution by levels or in heterogenous groups seems to be an option more linked to the school's educational project than a strategy to manage the diversity of levels of learning.

Furthermore, it was shown that the comprehensive model decreases the probability of opting for vocational training, including among students with low achievement. This may be a parents' effect or an effect of the school's educational model, because it directs students with low achievement towards baccalaureate, with a high probability of them struggling to gain the certificate and reducing the number of this profile of student doing vocational training, which they would be more likely to pass.

These results pose some sociopolitical challenges of a certain magnitude. The educational reforms over the last decades have tended to increase the prestige of vocational training by increasing the academic requisites to access it while simultaneously attempting to implement a comprehensive secondary education model. However, the comprehensive model, at least as it has been implemented, distances young people from vocational training, and in particular young people with a higher social background and higher academic 
achievement. To this effect, there are two possible future scenarios: either limiting the comprehensive model to increase the flow to vocational training, but increasing the link with the world of work and with better prospects of social promotion (in the line of the Germanic model); or extending the comprehensive model to upper secondary education, with less differentiation between the academic and the vocational tracks, by means of either integrating the curriculum (in line with the Nordic model) or by giving students different options to combine subjects (along the lines of the North American model). From recent experience in the debate on education policy in Spain, it seems that the first option is the one most likely to succeed. In the latest proposal for educational reform (December 2020), the establishment of a basic cycle in the 9th and 10th grades as a preparation prior to vocational training, with the aim of reducing early school leaving, in line with the strategic framework of the European Union, is proposed.

To end, it is pertinent to mention some limitations of this research such as those derived from the operationalization of some of the variables like achievement and student groupings. The fact of dichotomizing achievement to calculate the estimated probabilities means that some nuances are lost in the correlation with the rest of the variables in the model. The ability groupings derived from math and language tests and there is no information about whether this grouping affects just these or also other subjects, so the reality in the schools is likely to not be dichotomous like the constructed variable. Other variables not included in the model due to lack of information may intervene in preferences for the academic or vocational tracks, such as the existing offer in the students' vicinity, the specific guidance practices in the schools, and the possibilities of linking vocational training with higher education. Finally, the data analyzed are somewhat outdated and it is possible that school practices have changed. Unfortunately, in Spain, data are not collected periodically and systematically on the ability grouping, nor on the students' social origin, nor with a longitudinal perspective. One line of future research would be to update the data and incorporate more variables in the explanatory models.

Author Contributions: Conceptualization, R.M.; methodology, O.V. and A.S.-G.; data curation, O.V.; writing—original draft preparation, R.M.; writing—review and editing, R.M. All authors have read and agreed to the published version of the manuscript.

Funding: This research was funded by National Plan I + D of Ministry of Science, Spain (ref. CSO2016-79945-P).

Informed Consent Statement: Informed consent was obtained from all subjects involved in the study.

Data Availability Statement: Data will be available in the database of Centro de Investigaciones Sociológicas (ref. CSO2016-79945-P).

Conflicts of Interest: The authors declare no conflict of interest. The funders had no role in the design of the study; in the collection, analyses, or interpretation of data; in the writing of the manuscript, or in the decision to publish the results.

\section{References}

1. Echeverría, B.; Martínez, P. Diagnóstico de la Investigacion sobre la Formación Profesional Inicial en España (2005-2017); Fundación Bankia: Madrid, Spain, 2019.

2. Greinert, W.D. European vocational training systems: The theoretical context of historical development. In Towards a History of Vocational Education and Training (VET) in Europe in a Comparative Perspective; CEDEFOP, Office for Official Publications of the European Communities: Luxembourg, 2004.

3. Salvà-Mut, F.; Ruiz-Pérez, M.; Psifidou, I.; Oliver-Trobat, M.F. Formación profesional de grado medio y abandono temprano de la educación y la formación en España: Una aproximación territorial. Bordón Rev. Pedagog. 2020, 72, 95-116. [CrossRef]

4. Buechtemann, C.F.; Verdier, E. Régimes d'éducation et de formation professionnelle. Révue D'economie Polit. 1998, 108, 291-320.

5. Euler, D. El Sistema Dual en Alemania. ¿Es Posible Transferir el Modelo al Extranjero? Berterlsmann Stiflung: Barcelona, Spain, 2013.

6. Oakes, J. Limiting Opportunity: Student Race and Curricular Differences in Secondary Vocational Education. Am. J. Educ. 1983, 91, 328-355. [CrossRef]

7. Hyslop-Margison, E.J. An Assessment of the Historical Arguments in Vocational Education Reform. J. Career Tech. Educ. 2000, 17, 23-30. [CrossRef] 
8. Green, A.; Wolf, A.; Leney, T. Convergence and Divergence in European Education and Training Systems; Institute of Education: London, UK, 1999.

9. Dronkers, J. Education as the bakbone of inequality-European education policy: Constraints and possibilities. In Social Democracy and Education. The European Experience; Becker, F., Duffek, K., Mörschel, T., Eds.; Friedrich Ebert Stiflung: Berlin, Germany, 2008.

10. Weeks, A. Comprehensive Schools: Past, Present and Future; Methuen: London, UK, 1986.

11. García Garrido, J.L. Igualdad y libertad en la educación obligatoria: La experiencia comprensiva. Pers. Derecho 2004, 50, 411-432.

12. Raffe, D. Pathways Linking Education and Work: A Review of Concepts, Research, and Policy Debates. J. Youth Stud. 2003, 6, 3-19. [CrossRef]

13. Merino, R. Las sucesivas reformes de la formación profesional en España o la paradoja entre integración y segregación escolar. Arch. Analiticos Politicas Educ./Educ. Policy Anal. Arch. 2013, 21, 66. [CrossRef]

14. Merino, R. Two or three vocational training pathways? An assessment and the corrent situation in Spain. Eur. J. Vocat. Train. 2006, $1,52-67$.

15. Mons, N. Les Nouvelles Politiques Educatives: La France Fait-Elle les Bons Choix? Presses Universitaires de France: Paris, France, 2007.

16. Fernández Enguita, M. De la información al conocimiento ... pero en serio. Particip. Educ. 2014, 3, 50-57.

17. Hattie, J. Visible Learning: A Synthesis of over 800 Meta-Analyses Relating to Achievement; Routledge: London, UK, 2009.

18. Demanet, J.; Van Houtte, M. Resisting Education: A Cross-National Study on Systems and School Effects; Springer: Dordrecht, The Netherlands, 2019; Volume 2.

19. Cooper, B.; Glaesser, J. Qualitative Work and the Testing and Development of Theory: Lessons from a Study Combining Cross-Case and Within-Case Analysis via Ragin's QCA. Forum Qual. Soz. Forum Qual. Soc. Res. 2012, 13, 2.

20. Pàmies, J.; Castejón, A. Distribuyendo oportunidades: El impacto de los agrupamientos escolares en la experiencia de los estudiantes. Rev. Assoc. Sociol. Educ. 2015, 8, 335-348.

21. Puelles Benítez, M. Reflexiones sobre cuarenta años de educación en España o la irresistible seducción de las leyes. Hist. Mem. Educ. 2016, 3, 15-44. [CrossRef]

22. Homs, O. La Formación Profesional en España. Hacia la Sociedad del Conocimiento; Colección Estudios Sociales Núm. 25; La Caixa: Barcelona, Spain, 2008.

23. Baudelot, C.; Establet, R. L'école Capitaliste en France; Maspero: Paris, France, 1972.

24. Carabaña, J. Sobre educación y mercado de trabajo: Los problemas de la Formación Profesional. In Planificación de la Educación y Mercado de Trabajo; Graó, J., Ed.; Narcea: Madrid, Spain, 1988.

25. Merino, R. Formación profesional y género: Desigualdades que persisten, algunos cambios y debates pendienets. RASE Rev. Sociol. Educ. 2020, 13. [CrossRef]

26. Martínez, J.S.; Merino, R. Formación Profesional y desigualdad de oportunidades educativas. Témpora 2011, $14,13-37$.

27. Merino, R.; Garcia, M.; Torrents, D.; Valls, O. Separación del alumnado por niveles en $4^{\circ}$ de ESO y complejidad social de los centros. Límites y posibilidades del currículum comprensivo. Témpora Rev. Hist. Sociol. Educ. 2017, 19, 181-198.

28. Sarceda-Gorgoso, M.C.; Santos-González, M.C.; Sanjuán, M.M. A Formación Profesional Básica: ¿alternativa al fracaso escolar?/Basic Vocational Training: An alternative to school failure? Rev. Educ. 2017, 378, 75-98.

29. Valdés, M. La construcción del itinerario formativo postobligatorio: Efectos de la atención al bajo rendimiento sobre la expectativa académica. Tend. Soc. Rev. Sociol. 2019, 3, 77-104.

30. Elias, M.; Daza, L. Configuración y Reconfiguración de las Expectativas Educativas después de la Educación Obligatoria: Un Análisis Longitudinal. Int. J. Sociol. Educ. 2019, 8, 206-235. [CrossRef]

31. Merino, R.; Torrent, D. Bad Schools or Bad Pupils? School Effects on Misbehaviour in Barcelona. In Resisting Education: A Cross-National Study on Systems and School Effects; Demanet, J., Van Houtte, M., Eds.; Springer: Berlin, Germany, 2019.

32. Aguado, J.A.; Cano, F.J.; Sánchez Pérez, M.J. Segregación por género y Formación Profesional: Aportaciones al debate sobre la situación actual. RASE Rev. Sociol. Educ. 2020, 13, 308-327.

33. Troiano, H.; Torrent, D.; Daza, L. Compensation for poor performance through social background in tertiary education choices. Stud. High. Educ. 2019. [CrossRef]

34. Elias, M.; Merino, R.; Sánchez-Gelabert, A. Aspiraciones ocupacionales y expectativas y elecciones educativas de los jóvenes en un contexto de crisis. Rev. Esp. Sociol. 2020, 29, 27-46. [CrossRef] 